\title{
USE OF SPECTRAL INDICES TO IDENTIFY THE CHANGES \\ IN THE VEGETATION COMMUNITY OVER TIME AFTER RESTORING A PALUSTRINE WETLAND: A CASE STUDY OF SPENCER ISLAND REGIONAL PARK, EVERETT, WA.
}

\author{
CAROLina A. LiZANA
}

College of the Environment, University of Washington, Seattle, U.S. Corresponding author e-mail: clizana@uw.edu

Received: $11^{\text {th }}$ September 2019, Accepted: $12^{\text {th }}$ October 2019

\begin{abstract}
Wetland restoration can be measured over time using community vegetation as an effectiveness indicator of restoration actions. Spencer Island Regional Park is part of the tidal freshwater wetlands along the Snohomish river basin. Those wetlands are part of a complex ecosystems, in which they are included as a salmon corridor. This research analyzes the vegetation community changes over time after restored in 1996 on Spencer Island Regional Park, Everett, Washington State, U.S. I analyzed three spectral indices using segmentation and supervised classification of land cover from 1997 to 2018. I found that in the last 21 years, the areas with emergent palustrine vegetation and forests increased, in contrast to diminishing areas of upland and scrub-shrub classes. Those finds can be interpreted that the community vegetation advanced to higher wetland successional stages as upland areas have been colonized by emergent wetland plant communities. A linear regression model predicted that by 2025 , the difference between emergent and upland classes should increase. Empirical evidence is presented that support the integration of spectral indices to identify changes in community vegetation. However, it is recommended for future studies to include spectral indices and spatial information for soil and hydrology to deepen these results.
\end{abstract}

Keywords: Spatial analysis, landscape ecology, vegetation cover.

\section{INTRODUCTION}

Wetlands are among the most important ecosystems on Earth (Mitsch \& Gosselink, 2015). They stabilize water supplies, clean polluted waters, protect shorelines and recharge groundwater. Also, these ecosystems support rich biodiversity and provide unique habitats for a wide variety of flora and fauna. Tidal freshwater wetlands receive tidal influences but without the salt stress. These types of wetlands are very productive and contain high biodiversity. However, tidal freshwater wetlands are sensitive to a wide range of environmental disturbances that are forecast for the coming decades and centuries (Neubauer \& Craft, 2009). Wetland restoration has become a common practice to compensate environmental disturbances (Meli et al., 2014). Wetland restoration measures includes ecological succession of community vegetation (Bohnen \& Galatowitsch, 2001). The 
monitoring of wetland restoration is evaluated according to hydrology, soils or vegetation indicators. Thus, some of these indicators may include vegetation analysis as part of the evaluation of the success of the restoration measures (Galatowitsch et al., 1999). Changes in plant communities drive changes in land cover types, which modify the availability of natural biological habitats, thus affecting the overall coastal ecosystem (Biondini \& Kandus, 2006). Therefore, vegetation analysis is presented as an approach in the evaluation of restoration activities.

Spencer Island Spencer Island Region Park is part of the tidal freshwater wetlands along the Snohomish river basin, and it is an important estuary patch in this landscape because this location plays a pivotal role in the rearing of juvenile salmonids (Cordell et al., 1998). The wetlands of the site are buffers that moderate the anthropogenic impacts to salmon habitat and salmon life-cycle needs, through pollutant and sediment removal/settling, thermal regulation, streambank regulation, streambank stabilization and habitat corridor.

Water quantity and water quality has been modified in Spencer Island in the past years. Specifically, urbanization has affected water quantity, through increases in the frequency and magnitude of storm flows which causes channel incision, increased sedimentation and pollutant loading in streams. Historically, this area has been exposed to different landscape changes. In 1920, the land was diked for agriculture, cutting the area off from tidal and saltwater influence. Then, in 1989 the area was purchased by Snohomish County Parks and Recreation Department and Washington Department of Fish and Wildlife (Tanner et al., 2002). After that, as dikes were breached, the site began to be restored to an estuarine environment. Currently, the northern portion of Spencer Island is used for duck hunting, and the south is part of a Snohomish County park, which includes a restoration area that benefit habitat for salmon and other native species. In this study, I attempted to detect shifting of spatial distributions and vegetation community changes of Spencer Island Regional Park after restoring the wetlands by using remote sensing techniques.

Conventional detection of land cover change is time-consuming and labor-intensive (Lee $\&$ Yeh, 2009). The spatial distribution of land cover at different times can be analyzed by using remote sensing imagery; compared to conventional labor-intensive field investigation, remote sensing information not only saves time but also enhances the possibility of classifying the vegetation through spectral analyses (Lee \& Yeh, 2009; Xie et al., 2008). Remote sensing has long been recognized as a powerful tool for identifying wetlands (Guo et al., 2017). Moreover, wetland classification using remote sensing and GIS has been widely documented (Mahdavi et al., 2018; Williams \& Lyon, 1997). Spatial information about magnitude of vegetation cover is essential to initiate vegetation protection and evaluate restoration programs (He et al., 2005).

Landsat images were usually analyzed for mapping vegetation types in wetlands (Boyden et al., 2013). According to Adam et al. (2010), the most common image analysis methodology used in mapping wetland vegetation includes digital image classification (supervised or unsupervised), using multi-spectral data and vegetation index clustering (for example Normalized Difference Vegetation Index (NDVI), Modified Normalized Difference Water Index (MNDWI) and Normalized Difference Water Index (NDWI)). Other studies have used applied object-based image analysis and supervised classification to identify wetland vegetation community (Dronova et al., 2015; Dronova et al., 2011; O'Neil et al., 2018). Due to the ecological importance of the wetland, its sensitivity of land changes and the need to evaluate the effectiveness of the restoration actions, the objective of this study was analyzing how the vegetation community has changed over time on Spencer Island Regional Park, Everett, WA, after its restoration using Landsat images, object-based image and spectral analysis. If restoration has been successful, ergo, the vegetation community has 
continued the ecological succession, then it is expected the emergent community has been replaced over time to vegetation of greater successional stages, such as scrub-shrub or forested vegetation community.

\section{METHODS}

\section{Study Area}

Spencer Island Regional Park is located between the cities of Everett and West Lake Stevens, Washington State. The study area is 424 acres and it is surrounded by the corridors of Union Slough and Steamboat Slough, which are connected to the Snohomish River. The wetlands of Spencer Island have tidal influences and part of its water resources includes saltwater. This park is characterized as a refuge for a complex ecosystem, composed of different wetlands that includes different vegetation assemblages throughout the site: forested, scrub-shrub, riverine, emergent and aquatic bed, as well of a portion of upland areas.

Spencer Island contains two dominant Cowardin vegetation community types: palustrine emergent and palustrine forested (Cowardin et al., 1979). The palustrine emergent class is the most dominant class in the area. The emergent wetland class is characterized by erect, rooted, herbaceous hydrophytes, excluding mosses and lichens. This vegetation is present for most of the growing season in most years. These wetlands are usually dominated by perennial plants. The dominant vegetation present in Spencer Island Regional Park of this class are Carex spp, Typha latifolia, Galium aparine and Juncus balticus.

Palustrine forested is characterized by woody vegetation that is $6 \mathrm{~m}$ tall or taller. For palustrine forested class, the dominant species in the upper layer vegetation are Alnus rubra and Picea sitchensis. In the second strata the dominant species are Rosa nutkana, Gaultheria shallon, Spiraea douglasii and Rubus armeniacus. For the herbaceous strata, Phalaris arundinacea, Agrostis spp. and Poa spp. are the dominant species. Phalaris arundinacea is an invasive species that thrives in disturbed saturated or shallow inundated wetland areas with sources of nutrients and it is difficult to eradicate.

Although, scrub-shrub was not a dominant class of the Cowardin Classification, it is present in some areas of Spencer Island. Scrub-Shrub wetland includes areas dominated by woody vegetation less than $6 \mathrm{~m}$ (20 feet) tall. The species include true shrubs, young trees, and trees or shrubs that are small or stunted because of environmental conditions (Cowardin et al., 1979). The dominant vegetation for this class is integrated with Salix spp, Spiraea douglasii and Rubus armeniacus. Spencer Island has areas of aquatic bed vegetation, meaning presence of palustrine unconsolidated bottom with permanent flooded tidal water regime.

The Island possesses a diverse set of hydrologic regimes, and thus the vegetation can be temporarily, semi permanently or permanently flooded. Palustrine forested class is temporally flooded tidal. palustrine scrub-shrub is temporally flooded tidal with variations to seasonally flooded. The palustrine emergent vegetation is semi permanently flooded, and usually experiences inundation twice a day. There is palustrine unconsolidated bottom vegetation that is permanently flooded. In upland areas, it is present a scrub shrub and forest habitat along the dikes.

\section{Changes of the vegetation community analysis}

A hybrid Object-Based Classification and Index-Based Classification (supervised and unsupervised classification) was used to monitor the Spencer Island vegetation community 
changes over time using ArcMap Desktop 10.6 (Fig. 1). To analyze changes in the vegetation community over time, four temporal Landsat images were used with data acquisition dates of July 23, 1997 (Landsat 5 TM), July 29, 2005 (Landsat 5 TM), July 30, 2011 (Landsat 5 TM) and July 17, 2018 (Landsat 8 OLI). Images from these dates were selected based on availability, absence of clouds and seasonal consistency. All the selected images were acquired during the same month to avoid seasonal differences in the vegetation community. The images were obtained as radiometrically corrected data in digital number values and they were georeferenced at WGS 1984 UTM Zone $10 \mathrm{~N}$.

\section{Fig. 1: Methodology workflow}

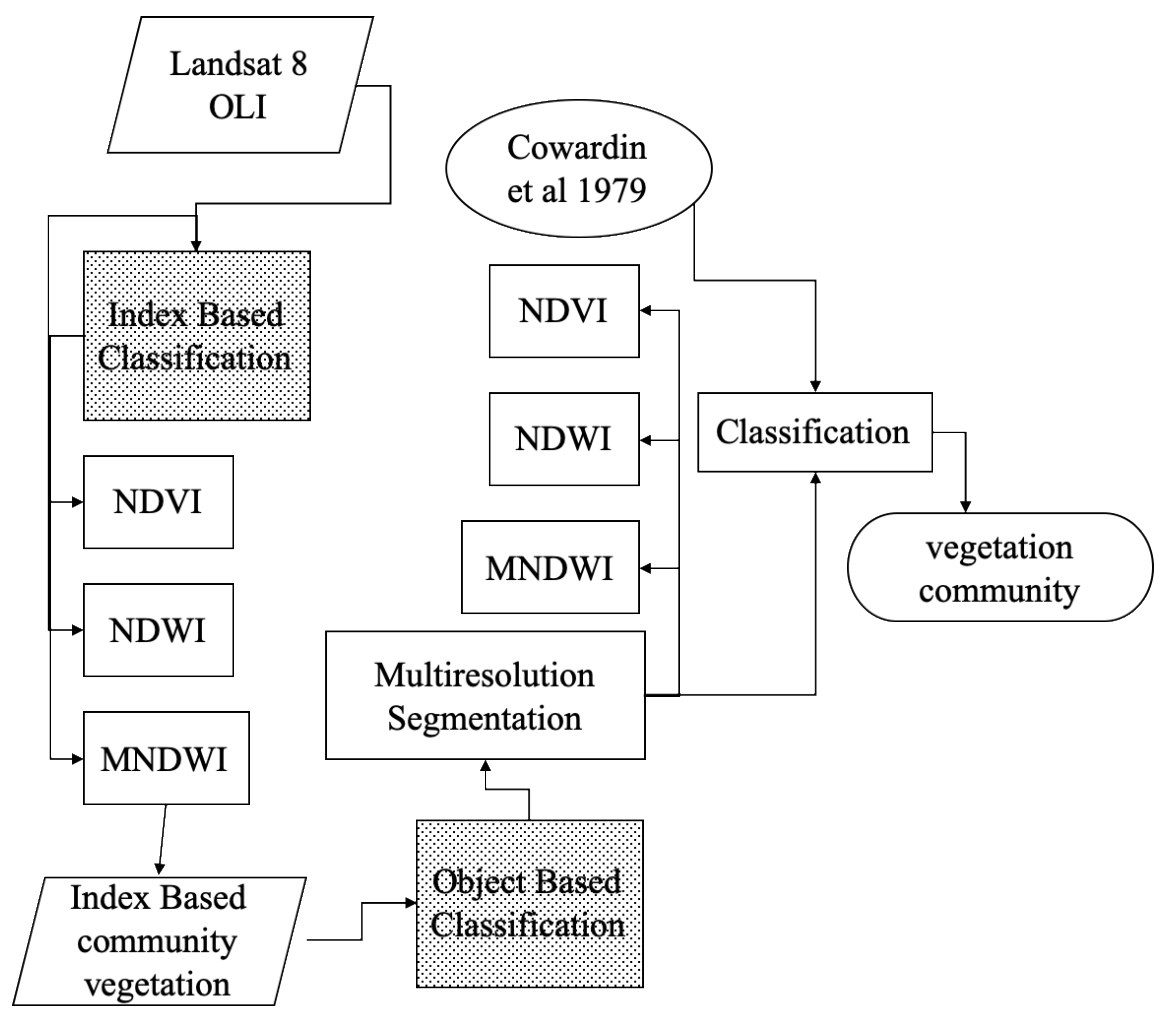

Normalized Difference Vegetation Index (NDVI), Normalized Difference Water Index (NDWI) and Modified Normalized Difference Water Index (MNDWI) were obtained for analyzing vegetation community conditions as described by Lane et al. (2014). This study complemented NDVI index with NDWI and MNDWI to improve visual resolution between vegetation community classification. NDVI quantifies vegetative "greenness" by measuring the difference between near-infrared (strongly reflected by vegetation) and red light (absorbed by vegetation) (Equation 1). Values of the NDVI range from -1.0 to 1.0. Positive values reflect vigorous and dense green biomass and negative values indicate no green biomass was detected. For flooded vegetation, NDVI result in small positive or zero values. Open water yields negative values. However, changes in the hydrology can produce spurious NDVI values due to water temporarily flooding or covering areas of vegetative growth (Lane et al., 2014). 


$$
N D V I=\frac{N I R-R e d}{N I R+R e d}
$$

\section{Equation 1. NDVI}

NDWI delineates and quantifies changes in open water as described in (McFeeters, 1996). The NDWI makes use of visible green light and reflected near-infrared radiation to enhance the detected presence of open water features while eliminating the detected presence of soil and terrestrial vegetation (Equation 2). Values of the NDWI range from -1.0 to 1.0. Water features in NDWI present positive values, while vegetation and soil usually have zero or negative values (McFeeters, 1996).

$$
N D W I=\frac{\text { Green }-N I R}{\text { Green }+N I R}
$$

Equation 2. NDWI, When NIR: Near infrared

MNDWI is a modified version of the NDWI (Equation 3) as described in $\mathrm{Xu}$ (2006). MNDWI enhances accurate detection of open water features by efficiently suppressing and even eliminating signals from built-up land. Values of the MNDWI range from -1.0 to 1.0. MNDWI produces greater positive values than NDWI, separating the water from the more negative values associated with buildup land, soils and vegetation. This index is defined as:

$$
M N D W I=\frac{\text { Green }-M I R}{\text { Green }+M I R}
$$

Equation 3. MNDWI, When MIR: Middle infrared.

Image segmentation is the process of partitioning a digital image into multiple segments (sets or clusters of pixels). This process allowed for the clustering of similar index values, and it was used for object recognition and classification. For Unsupervised Classification, image segmentation was applied by each index (NDVI, NDWI and MNDWI) for the four temporal Landsat images (1997, 2005, 2011 and 2018). The classification was applied to the images from the four different years and results were used to detect land cover change. After image segmentation, vegetation community were defined according to structure (physiognomy) (Cowardin et al., 1979) resulting in six landcover types including five vegetation community types: 1) forested, 2) scrub-shrub, 3) emergent, 4) aquatic-bed 5) upland and also, 6) riverine areas. These land cover types were then identified using Maximum-Likelihood Classification. The accuracy of the classifications has been evaluated using ground control points from throughout the imagery.

Community vegetation changes was calculated using the delta area for each vegetation community type. Finally, a simple linear regression model (Kutner et al., 2005) was applied to each class to determine the trends in community vegetation classes. These trends were extrapolated to estimate future vegetation community types in the year 2025 assuming similar land management practices will continue. 


\section{RESULTS}

The vegetation community changed substantially between 1997 and 2018 (Table 1), shifting from scrub shrub and uplands dominated vegetation classes in 1997 to primarily the emergent vegetation class in 2018. The proportion of aquatic bed remained relatively constant over time. The error matrix and associated accuracy of the classifications indicated that overall accuracy was 0.72 and Kappa index of 0.65 , which means classification agrees with the reference data and confirm that classification is significantly better than a random classification. The main trend of the vegetation community for the four years of study are exposed in Fig.2.

Table 1: Community vegetation classes areas (acres, \%) by year 1997, 2005, 2011 and 2018 (Cowardin et al., 1979)

Year

Cowardin Class

\begin{tabular}{|c|c|c|c|c|c|c|c|c|}
\hline 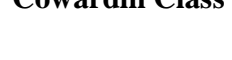 & 1997 & $(\%)$ & 2005 & $(\%)$ & 2011 & $(\%)$ & 2018 & $(\%)$ \\
\hline Emergent & 88.42 & $21 \%$ & 161.67 & $38 \%$ & 248.69 & $59 \%$ & 226.63 & $53 \%$ \\
\hline Forested & 69.70 & $16 \%$ & 94.65 & $22 \%$ & 49.23 & $12 \%$ & 81.06 & $19 \%$ \\
\hline Scrub Shrub & 170.20 & $40 \%$ & 100.91 & $24 \%$ & 86.60 & $20 \%$ & 71.84 & $17 \%$ \\
\hline Aquatic Bed & 1.70 & $0 \%$ & 0.88 & $0 \%$ & 2.91 & $1 \%$ & 1.03 & $0 \%$ \\
\hline Riverine & 16.02 & $4 \%$ & 49.20 & $12 \%$ & 16.55 & $4 \%$ & 27.00 & $6 \%$ \\
\hline Upland & 78 & $18 \%$ & 16.10 & $4 \%$ & 20.82 & $5 \%$ & 16.40 & $4 \%$ \\
\hline
\end{tabular}

Fig. 2: Main trend of the vegetation community on Spencer Island Regional Park for four years of study (1997, 2005, 2011 and 2018)

\section{Main trend for each vegetation community on the study site $(\%)$}

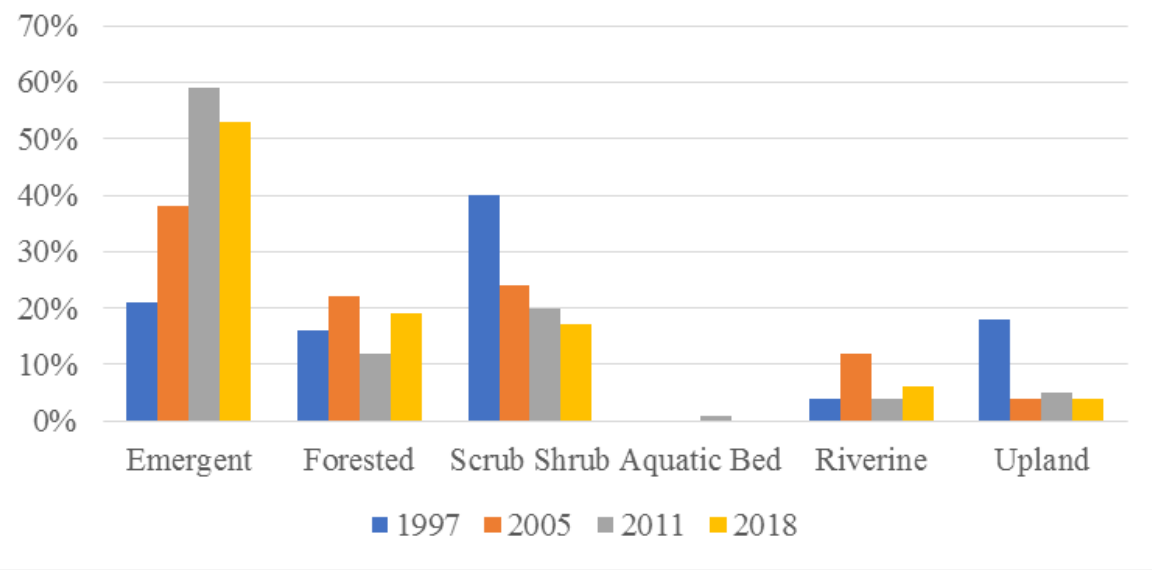


Lizana C.A.: Use of Spectral Indices to Identify the Changes in the Vegetation Community Over Time After Restoring a Palustrine Wetland: A Case Study of Spencer Island Regional Park, Everett, WA

Fig. 3: Object-based and index-based classification results for Spencer Island Region Park in 1997, 2005, 2011 and 2018
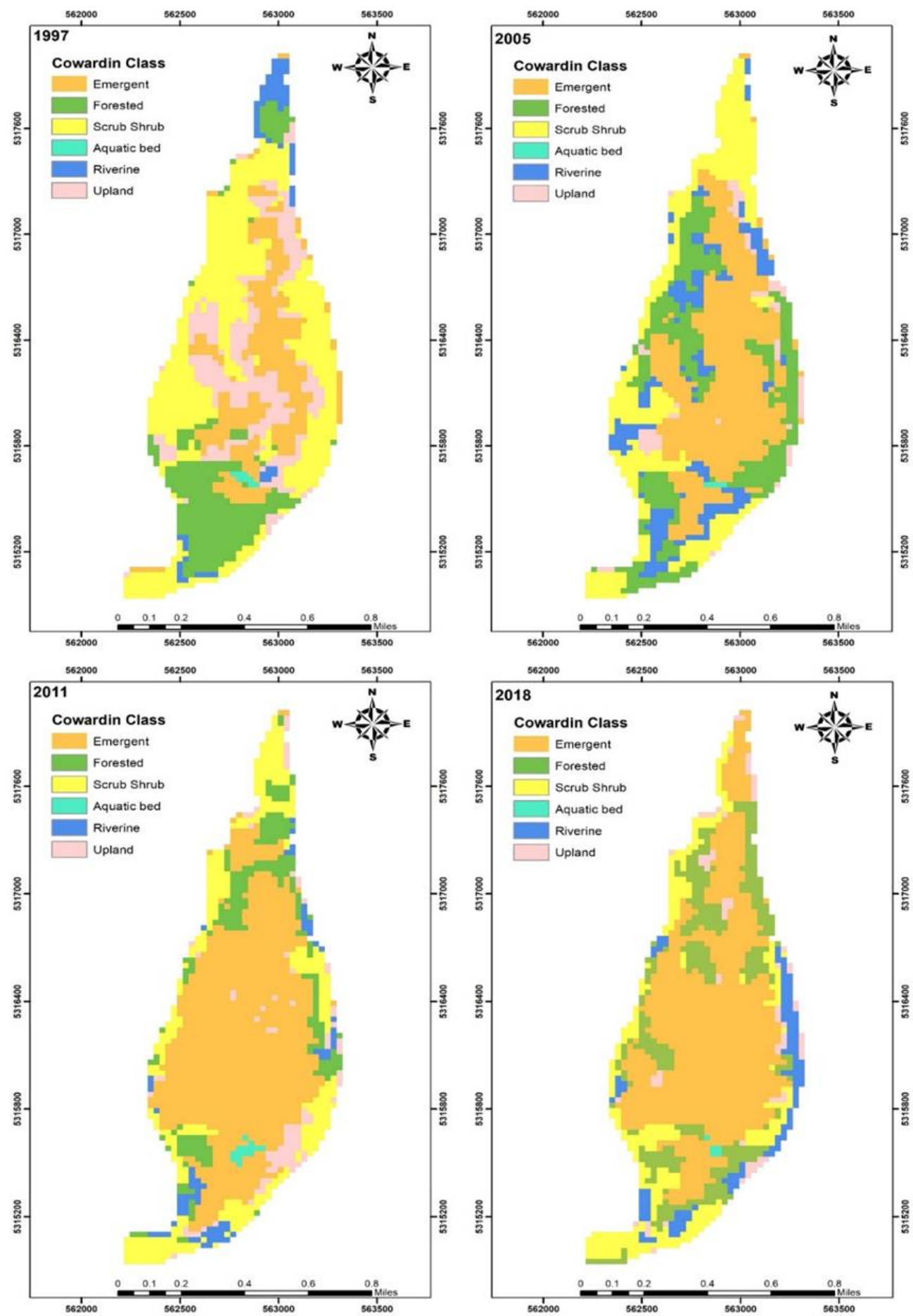
Image analysis and wetland surveys clearly showed this increase in spatial coverage of the emergent vegetation class over time (Fig. 3). Additionally, the replacement of scrub shrub vegetation located in the north west of the study area over time by forested vegetation was distinct. Explicit spatial patterns for the other community vegetation classes were not evident.

Linear regression of community vegetation types over the four years reflect the substantive increase in the emergent vegetation class and decrease in the upland vegetation classes (Table 2). Assuming this trend continues, the emergent vegetation class is expected to continue to increase in area while the upland class continues to be replaced.

Table 2: Estimated community vegetation classes by the year 2025 (acres) assuming linear regression trends continue

\begin{tabular}{lllll} 
Cowardin Class & $\mathbf{2 0 2 5}$ & $\mathbf{( \% )}$ & Linear regression & $\mathbf{R}^{\mathbf{2}}$ \\
\hline Emergent & 306.38 & $70 \%$ & $\mathrm{y}=7.2713 \mathrm{x}-14418$ & 0.8088 \\
Forested & 72.26 & $17 \%$ & $\mathrm{y}=-4.5628 \mathrm{x}+9268.3$ & 0.8746 \\
Scrub Shrub & 28.63 & $7 \%$ & $\mathrm{y}=-0.0782 \mathrm{x}+230.62$ & 0.0013 \\
Aquatic Bed & 1.538 & $0 \%$ & $\mathrm{y}=-0.0029 \mathrm{x}+7.4105$ & 0.0008 \\
Riverine & 28.88 & $7 \%$ & $\mathrm{y}=0.0965 \mathrm{x}-166.53$ & 0.0031 \\
Upland & 0 & $0 \%$ & $\mathrm{y}=-2.7095 \mathrm{x}+5472.9$ & 0.6413
\end{tabular}

\section{DISCUSSION}

The purpose of this investigation was to identify the community vegetation changes on Spencer Island Regional Park after restored. This investigation was important because it was necessary evaluate the effectiveness of the restoration actions, due the site has been exposed to different disturbances. Based on the data collected, the hypothesis was verified because the community vegetation has been advanced to higher wetland successional stages.

In particular, emergent community vegetation exhibited a positive change in their area between 1997 and 2018. This find can be explained because the area presented stable hydrologic conditions, which was associated with normal average rainfall and streamflow, which promoted emergent and aquatic vegetation (Stevens et al., 2003). In contrast, scrub shrub and upland classes decreased in area for the same period. In general, these changes could be attributed to the fact that, prior to 1997, the site was restored, and the dikes were breached. Therefore, it can be deduced that the community vegetation advanced to higher wetland successional stages as upland areas have been colonized by emergent wetland plant communities. This is consistent with what has been found in previous research. Williams \& Lyon (1997) states upland sectors decrease as part of the succession giving away to colonization of more complex stages, which would confirm the explanation of the findings of this research. A similar conclusion was reached by Bork et al. (2013), the change of community vegetation was studied after implementing restoration measures in an area that was previously diked and used for agriculture. They found after restoring the site, there was an increase in the area of forested communities and a decrease in uplands areas. 
The growth of emergent class may be due to the increase of persistent herbaceous species. At the same time, it is believed that there was a change from the cover of scrub shrub to forested. This would explain the decrease of the scrub shrub area and the increase in forested. For upland areas, it is believed that their decrease in area can be explained by the colonization of invasive herbaceous species such as Phalaris arundinacea (reed canarygrass), and therefore, these areas would be classified as emergent. A similar pattern of results was obtained by Tu et al. (2001), they found that in the transitional zone between the emergent plant community and the upland, Phalaris arundinacea was often observed to colonize these areas, displacing other native species from emergent zones.

By 2025, the predictive model forecasts that areas of emergent and forested communities should be increased, and the upland areas should gradually be marginalized from the study area. Although the predictive model shows a linear trend of the area for plant communities, it is recommended to improve the results with the use of satellite images of high spatial and spectral resolution in order to be able to distinguish plant communities with greater precision. Because wetlands are influenced by soils and their hydrology, it is recommended for future studies to include spectral indices and spatial information of soil and hydrology to deepen these results. Specifically, it is important to consider hydrological characteristics because these results can be related with water levels, especially if the wetland has tidal influences. For example, Williams \& Lyon (1997) found that scrub-shrub and emergent classes decreased during higher water levels and increased during lower water level.

In the present research, objective evidences are presented that support the integration of spectral indices such as NDVI, MNDWI and NDWI to identify changes in the community vegetation using object-based approach. Object-Based classification is one of the most used image processing routines in remote sensing (Chin-Hsing \& Tu, 1996) and has the highest mean overall accuracy for wetland detection (De Roeck et al., 2008). The use of remote sensors and geographic information systems to classify wetland has been widely used due to the time efficiency of the method, relatively low costs (compared to on-the-ground human hours) and availability of the data sources (Hwang \& Um, 2015). Because of that, this study is presented as an effective alternative to monitor community vegetation overtime in a tidal freshwater wetland.

Finally, the principal implications of this study are: (1) Remote sensing tools, especially spectral indices applications, offer a quantitative approach that help to monitor vegetation community after restored. (2) Object-based analyses of systems can be effectively leveraged to capture vegetation community changes responds to restoration activities. (3) The method for monitoring wetland restoration reported here can be implemented cost efficient with object-based tools.

\section{ACKNOWLEDGEMENTS}

This study was part of the requirements of the Certificate in Wetlands Science and Management of University of Washington, in which contributed Shelby Petro and Fiona McNair.

\section{REFERENCES}

Adam, E., Onisimo, M., \& Rugege, D. (2010). Multispectral and hyperspectral remote sensing for identification and mapping of wetland vegetation: a review. Wetlands Ecology Management, 18, 281-296. doi:10.1007/s11273-009-9169-z. 
Biondini, M., \& Kandus, P. (2006). Transition matrix analysis of land-cover change in the accretion area of the Lower Delta of the Paraná River (Argentina) reveals two succession pathways. Wetlands, 26(4), 981-991. https://doi-org.offcampus.lib.washington.edu/ 10.1672/0277-5212(2006)26[981:TMAOLC]2.0.CO;2.

Bohnen, J., \& Galatowitsch, S. M. (2001). Biomonitoring and Management of North American Freshwater Wetlands. (R. Rader, D. Batzer, \& S. Wissinger, Editoři) New York, NY, U.S.: John Wiley and Sons.

Bork, S., Pypker, T. G., Maclean, A. L., \& Hribljan, J. A. (2013). A Case Study in Large-scale Wetland Restoration at Seney National Wildlife Refuge, Upper Michigan, $\begin{array}{llll}\text { U.S.A. The American } & \text { 286-302. }\end{array}$ doi:10.1674/0003-0031-169.2.286.

Boyden, J., Joyce, K. E., Boggs, G., \& Wurm, P. (2013). Object-based mapping of native vegetation and para grass (Urochloa mutica) on a monsoonal wetland of Kakadu NP using a Landsat 5 TM dry-season time series. Journal of Spatial Science, 58(1), 53-77. doi:10.1080/14498596.2012.759086.

Cordell, J. R., Higgens, H., Tanner, C., \& Aitkin, J. K. (1998). Biological Status of Fish and Invertebrate Assemblages in a Breaked-Dike Wetland Site at Spencer Island, Washington. Seattle: Seattle Fisheries Research Institute.

Cowardin, L. M., Carter, V., Golet, F. C., \& LaRoe, E. T. (1979). Classification of wetlands and Deepwater habitats of the United States. U.S. Fish and Wildlife Service, Department of Interior. Washington, D.C.: U.S. Fish and Wildlife Service.

De Roeck, E. R., Verhoest, N. E., Miya, M. H., Lievens, H., Batelaan, O., Thomas, A., a další. (2008). Remote Sensing and Wetland Ecology: A South African Case Study. Sensors, 8(5), 3542-3556.doi: 10.3390/s8053542.

Dennison, W. C., Orth, R. J., Moore, K. A., Stevenson, J. C., Cart, V., Kollar, S., a další. (1993). Assessing water quality with submerged aquatic vegetation. Bioscience, 43, 86-94. doi:10.2307/1311969.

Dronova, I., Gong, P., \& Wang, L. (2011). Object-based analysis and change detection of major wetland cover types and their classification uncertainty during the low water period at Poyang Lake, China. Remote Sensing of Environment, 115(12), 3220-3236. doi:10.1016/j.rse.2011.07.006.

Dronova, I., Gong, P., Wang, L., \& Zhong, L. (2015). Mapping dynamic cover types in a large seasonally flooded wetland using extended principal component analysis and object-based classification. Remote Sensing of Environment, 158, 193-206. doi:10.1016/j.rse.2014.10.027.

Galatowitsch, S. M., Budelsky, R., \& Yetka, L. (1999). An International Perspective on Wetland Rehabilitation. (W. J. Streever, Editor) Springer, Dordrecht.

Guo, M., Li, J., Sheng, C., Xu, J., \& Wu, L. (2017). A Review of Wetland Remote Sensing. Sensors, 17(4), 777. doi:10.3390/s17040777.

He, C., Zhang, Q., \& Li, Y. (2005). Zoning grassland protection area using remote sensing and cellular automata modeling - a case study in Xilingol steppe grassland in northern China. Journal of Arid Environments, 63, 814-826. doi:10.1109/IGARSS.2004.1369904.

Hwang, Y. S., \& Um, J. S. (2015). Monitoring the Desiccation of Inland Wetland by Combining MNDWI and NDVI: A Case Study of Upo Wetland in South Korea. Journal of korea Spatial Information Society, 23(6), 31-41. doi:10.12672/ksis.2015.23.6.031. 
Lizana C.A.: Use of Spectral Indices to Identify the Changes in the Vegetation Community Over Time After Restoring a Palustrine Wetland: A Case Study of Spencer Island Regional Park, Everett, WA

Chin-Hsing, C., \& Tu, T. (1996). Computation reduction of the maximum likelihood classifier using the Winograd identity. Pattern Recognition, 29(7), 1213-1220.doi:10.1016/0031-3203(95)00149-2.

Kutner, M. H., Nachtsheim, C., Neter, J., \& Li, W. (2005). Applied linear statistical models. New York, NY, U.S.: McGraw-Hill/Irwin.

Lane, C. R., Liu, H., Autrey, B. C., Anenkhonov, O. A., Chepinoga, V. V., \& Wu, Q. (2014). Improved Wetland Classification Using Eight-Band High Resolution Satellite Imagery and a Hybrid Approach. Remote sensing, 6, 12187-12216. doi:10.3390/rs61212187.

Lee, T., \& Yeh, H. (2009). Applying remote sensing techniques to monitor shifting wetland vegetation: A case study of Danshui River estuary mangrove communities, Taiwan. Ecological Engineering, 35(4), 487-496. doi: 10.1016/j.ecoleng.2008.01.007.

Mahdavi, S., Salehi, B., Granger, J., Amani, M., Brisco, B., \& Huang, W. (2018). Remote sensing for wetland classification: a comprehensive review. GIScience \& Remote Sensing, 55(5), 623-658. doi:10.1080/15481603.2017.1419602.

McFeeters, S. K. (1996). The use of the Normalized Difference Water Index (NDWI) in the delineation of open water features. International Journal of Remote Sensing, 17(7), 1425-1432. doi:10.1080/01431169608948714.

Meli, P., Rey Benayas, J., Balvanera, P., \& Martínez Ramos, M. (2014). Restoration enhances wetland biodiversity and ecosystem service supply, but results are context-dependent: a meta-analysis. PloS one, 9(4), e93507. doi:10.1371/journal.pone.0093507.

Mitsch, W. J., \& Gosselink, J. G. (2015). Wetlands (Sv. Fifth edition). Hoboken, New Jersey, U.S.: John Wiley \& Sons, Inc.

Neubauer, S. C., \& Craft, C. B. (2009). Global change and Tidal Freshwater Wetlands: Scenarios and impacts. V A. Barendregt, D. Whigham, A. Baldwin, \& D. W. Aat Barendregt (Editor), Tidal Freshwater Wetlands (str. 320). Backhuys Publishers \& Margraf Publishers.

O’Neil, G., Goodall, J., \& Watson, L. (2018). Evaluating the potential for site-specific modification of LiDAR DEM derivatives to improve environmental planning-scale wetland identification using Random Forest classification. Journal of Hydrology, 559, 192-208. doi:10.1016/j.jhydrol.2018.02.009.

Stevens, C. E., Gabor, T. S., \& Diamond, A. W. (2003). Use of Restored Small Wetlands by Breeding Waterfowl in Prince Edward Island, Canada. Restoration Ecology, 11, 3-12. doi:10.1046/j.1526-100X.2003.00107.x.

Tanner, C. D., Cordell, J. R., Rubey, J., \& Tea, L. M. (2002). Restoration of Freshwater Intertidal Habitat Functions at Spencer Island, Everett, Washington. Restoration Ecology, 10(3), 564-576. doi:10.1046/j.1526-100X.2002.t01-1-02034.x.

Tu, M., Hurd, C., \& Randall, J. M. (2001). Weed Control Methods Handbook: Tools \& Techniques for Use in Natural Areas. The Nature Conservancy, Wildland Invasive Species Team. http://tncweeds.ucdavis.edu.

Williams, D., \& Lyon, J. (1997). Historical aerial photographs and a geographic information system (GIS) to determine effects of long-term water level fluctuations on wetlands along the St. Marys River, Michigan, USA. Aquatic Botany, 58(3-4), 363-378. doi:1016/S0304-3770(97)00046-6.

Xie, Y., Sha, Z., \& Yu, M. (2008). Remote sensing imagery in vegetation mapping: a review. Journal of Plant Ecology, 1(1), 9-23. doi:10.1093/jpe/rtm005.

$\mathrm{Xu}, \mathrm{H}$. (2006). Modification of normalised difference water index (NDWI) to enhance open water features in remotely sensed imagery. International Journal of Remote Sensing, 27(14), 3025-3033. doi:10.1080/01431160600589179 